\title{
THE DARK KNIGHT RISES: KITA BUTUH SIMBOL UNTUK MENGGERAKKAN
}

\author{
Danu Widhyatmoko \\ Visual Design Communication, School of Design, BINUS University \\ Jln. K.H. Syahdan No. 9, Palmerah, Jakarta Barat 11480 \\ danu@binus.edu
}

\begin{abstract}
The dark knight rises: We Need Symbols to Make Movements is a writing that covers values existing in the last movie of Batman trilogy: The Dark Knight Rises (TDKR). In the film, it is described how batman is not only presented as a hero who saved the town, but also is presented as a symbol that keeps hope of the Gotham city society. Through this writing, it is also discussed the relation between TDKR and the recent condition of Indonesia.
\end{abstract}

Keywords: The Dark Knight Rises, Batman, Symbol

\begin{abstract}
ABSTRAK
The Dark Knight Rises: Kita Butuh Simbol untuk Menggerakkan adalah tulisan yang mengulas nilainilai yang terdapat di film terakhir dari trilogi Batman: The Dark Knight Rises (TDKR). Di dalam film tersebut dilukiskan Batman tak hanya hadir sebagai seorang pahlawan yang menyelamatkan kota, tetapi juga Batman dapat hadir sebagai sebuah simbol yang menjaga harapan dari masyarakat kota Gotham. Lewat tulisan ini juga akan dibahas relasi yang terdapat di film TDKR tersebut dengan keadaan yang berlangsung di Indonesia. (DW)
\end{abstract}

Kata kunci: The Dark Knight Rises, Batman, Simbol 


\section{PENDAHULUAN}

Hilangnya harapan adalah keadaan paling menyedihkan dari sebuah kehidupan. Tak hanya kehidupan sebagai individu, tetapi juga lingkup berbasis kelompok ataupun komunitas dari yang paling kecil (keluarga) hingga negara. Hilangnya harapan dapat berarti hilangnya keinginan, hilangnya arah dan tujuan dalam menjalani kehidupan. Tanpa adanya arah dan tujuan berarti berhentinya kehidupan itu sendiri. Setiap individu, baik itu pribadi maupun bagian dari organisasi, secara sadar harus senantiasa mencari cara untuk terus mempertahankan harapan yang dimilikinya. Cara-cara tersebut dicari dengan beragam cara baik lewat cara pribadi maupun kolektif.

Salah satu bentuk cara untuk menjaga harapan adalah dengan membangun simbol-simbol yang sanggup memberikan inspirasi; simbol yang dapat menjaga harapan hingga gerak kehidupan dapat terus bergulir. Dengan simbol, individu dapat terus meraih harapan yang diinginkan. Secara organisasi, organisasi tidak akan kehilangan arah karena terus bergerak mencapai tempat yang ingin dituju bersama-sama.

\section{METODE PENELITIAN}

Penulisan ini disusun menggunakan pendekatan studi literatur untuk mendapatkan data-data pendukung serta mencari kerangka teori guna menguatkan hasil penulisan. Kemudian setelah data didapatkan, dilakuakan analisis data reflektif. Analisis reflektif adalah metode analisis data yang berpedoman pada cara berpikir reflektif. Pada dasarnya metode ini adalah kombinasi yang kuat antara berpikir deduktif dan induktif, atau dengan mendialogkan data teoretis dan empiris secara bolak balik dengan kritis.

Dengan metode analisis reflektif, penulis mencari makna yang terkandung dari hasil pengumpulan data yang telah dilakukan. Kemudian, diperbandingkan antara literatur yang ada dengan keadaan ataupun fenomena yang tertangkap. Dari perbandingan tersebut dapat diperoleh simpulan data yang rasional dan ilmiah.

\section{HASIL DAN PEMBAHASAN}

Durasi 165 menit seolah tak cukup untuk memuaskan mata atas keindahan gambar demi gambar yang tertuang dalam akhir sebuah trilogi saga Batman (The Dark Knight). Christopher Nolan, Sang Sutradara, telah berhasil membawa sebuah dimensi baru atas tutur visual fiksi komik ke dalam nuansa film yang realistis. Nolan membawa trilogi Batman dengan amunisi cerita yang sedemikian cerdas, dengan bumbu kenakalan di sana-sini, dan didukung oleh karakter-karakter dengan pendekatan fenomenal: Joker tidak pernah tampil sedemikian menakutkan sebelumnya, begitu pun dengan Bane yang dapat hadir begitu menggetarkan. Aksi-aksi fantastis dan dibalut oleh teknis visual yang sangat menakjubkan. Teknologi terbaru dunia film diusung dengan cermat tanpa harus membabi buta memanfaatkannya. Semua tersaji utuh dalam membangun kekuatan cerita

Nolan membutuhkan karakter Bane untuk melakukan teror yang keras dalam akhir saga di The Dark Knight Rises (TDKR). Komik Batman: Bane of the Demon 1 (Maret 1998) menuliskan, Bane sangatlah cerdas, Ra's al Ghul (DC Comics, 1998) mengatakan: "Bane memiliki kemampuan otak terbesar yang pernah ia temui". Di penjara ia belajar sendiri berbagai disiplin ilmu hingga sampai tingkat pemahaman yang setara dengan para ahli terkemuka masing-masing bidang. Dia menguasai 
enam bahasa secara aktif dan setidaknya dua bahasa misterius serta bahasa kuno yang telah mati, di antaranya adalah Spanyol, Inggris, Urdu, Persia, dan Latin. Bane memiliki kemampuan memori eidetik (photographic memory). Dalam satu tahun, ia mampu untuk menyimpulkan identitas rahasia Batman. Sungguh Bane adalah lawan yang setimpal dengan kecerdasan Bruce Wayne (Batman). Lebih dari itu, kemampuan fisiknya pun di atas rata-rata, hasil tempaan dari guru yang sama (Ra's al Ghul) menjadikan Bane lawan yang sepadan dengan kemampuan fisik Bruce Wayne, terlebih delapan tahun lamanya Bruce Wayne menggantungkan kostum Batman yang dimilikinya, pensiun dari aktivitas apapun di luar istananya. Fisik Bruce Wayne rapuh, jauh berjarak dengan kemampuan yang dimiliki oleh Bane yang sedemikian primanya.

Bane adalah paduan kecerdasan, kekuatan dan, teror yang sempurna.Bursa Efek Gotham dipilih menjadi awal dari segala teror, sebagai bentuk representasi perlawanan atas kekuasaan kelas berpunya, teror tersebut berusaha untuk mengambil kekuasaan lalu diberikan kembali kepada rakyat.Batman yang kembali turun gunung dan berupaya untuk menghentikan teror demi teror yang tercipta telah kehilangan daya fisiknya. Nolan dengan cerdas menerjemahkan satu adegan ikonis dari komik Batman, "The Man Who Broke the Bat" (DC Comics, 1993), Bane dengan brutal mematahkan tulang punggung Batman dengan lututnya. Batman luluh lantak dihajar oleh kedigdayaan Bane.Lalu mulailah teror yang lebih sistematis tercipta, merata di seluruh penjuru Gotham.Masyarakat tersandera, bahkan seluruh polisi dapat dikunci di bawah tanah. Sistem telah gagal, kota tak dapat mengurus dirinya sendiri. Kendali aktivitas kehidupan berpindah tangan ke tangan-tangan kejahatan, hukum berjalan sekehendak penguasa. Masyarakat kehilangan harapan, tak mampu berbuat banyak, ketakutan menjadi kendali luar biasa yang mengatur gerak masyarakat. Kerusakan demi kerusakan terus berjalan, dengan harapan yang semakin sirna, terlebih nuklir telah bersiap meledak, terkunci pada titik waktu yang telah ditentukan. Masyarakat dipenuhi oleh rasa apatis karena hilangnya harapan.Hingga satu titik, revolusi dianggap menjadi jalan keluar.

Teori Pemusatan Simbolis yang kerap dikenal dengan nama analisis bertemakan fantasi (fantasy theme analysis) mengatakan bahwa sebagai titik awal adalah gambaran individu tentang realitas yang dituntun oleh cerita-cerita yang menggambarkan bagaimana segala sesuatu itu diyakini ada. Cerita-cerita atau tema-tema fantasi ini diciptakan dalam interaksi simbolis dalam kelompokkelompok kecil serta merta berpindah dari satu orang ke orang lain dari satu kelompok ke kelompok lain untuk berbagi sebuah pandangan tentang dunia (Littlejohn \& Foss, 2009). Teori tersebut menjelaskan alasan Nolan menggunakan simbol Batman sebagai media yang dapat menjaga harapan masyarakat, menjaga fantasi warga Gotham. Batman delapan tahun yang lalu adalah sosok yang mampu menjaga keamanan Gotham, walaupun isu yang beredar malah sebaliknya. John Blake, seorang polisi, begitu menjaga fantasi tersebut lewat guratan kapur berbentuk simbol Batman yang kerap ia torehkan di dinding-dinding kota. Ia dan beberapa orang anak menjaga harapan tersebut. Simbol tersebut juga yang diketengahkan oleh Nolan dengan kehadiran bombastis khas Hollywood berupa simbol Batman yang terwujud dari api yang membakar sisi gedung. Batman yang menyulut api tersebut. Batman adalah simbol yang menjaga harapan masyarakat. Sebuah simbol yang dapat dilihat oleh masyarakat Gotham secara luas. Masyarakat pada dasarnya akan senantiasa butuh simbol yang berjalan di luar institusi-institusi yang ada. Masyarakat tidak lagi membutuhkan cerita-cerita yang utuh, tetapi cukup menyingkatnya dengan hanya memberikan sebuah "pemicu" atau isyarat simbolis (Littlejohn \& Foss, 2009). Di situlah fungsi simbol Batman hadir.

Tema-tema fantasi dan bahkan pandangan retorika yang lebih besar, terdiri atas karakter, alur, tempat, dan perantara pendukung (Littlejohn \& Foss, 2009). Karakter dapat berupa pahlawan, penjahat, atau pemain pendukung lainnya. Karakter Batman mewakili posisi tersebut. Dia adalah sosok pahlawan yang diharapkan hadir di tengah kekacauan yang diusung oleh Bane. Alur adalah gerak perkembangan cerita, kekacauan yang tercipta menyisakan harapan akan kehadiran Batman, karena kekacauan-kekacauan yang sebelumnya hadir di tengah kota Gotham, dapat terselesaikan oleh Batman. Tempat adalah latar tempat peristiwa tersebut berlangsung, Gotham adalah tempat tersebut. Termasuk di dalamnya lokasi, perlengkapan, dan lingkungan sosio kultural. Akhirnya, perantara yang 
mendukung (sanctioning agent) elemen ini adalah sebuah sumber yang dapat mengesahkan cerita tersebut. Perantara ini dapat berupa keyakinan pada Tuhan, komitmen pada keadilan dan demokrasi, atau bahkan kepercayaan terhadap lawan. Lewat TDKR, warga Gotham mendapatkan pengesahan cerita lewat cerita kepahlawanan Batman.

Ketika manusia dapat berbagi tema-tema fantasi, pandangan retorika menyatukan mereka dan memberi pemahaman tentang identifikasi dengan menggunakan sebuah realitas. Kemudian mereka membangun atau mempertahankan kesadaran bersama (shared consciousness) sebuah kelompok atau komunitas (Littlejohn \& Foss, 2009). Ide dari TDKR bukan memberikan peran Batman sebagai dokter yang menyembuhkan segala penyakit yang ada. Ia adalah simbol yang dapat hadir di diri siapapun di dalam kelompok atau komunitas; ia memberikan semangat untuk memperbaiki. Ia sanggup menggerakkan tiap elemen masyarakat yang ada untuk bersama memperbaiki lembaga juga struktur yang telah rusak. Kehadiran tersebut jelas tampak pada saat lembaga polisi sanggup hadir kembali ke tengah kota, mereka bersama-sama siap berjuang untuk melawan Bane dengan para anggotanya. Perang pun tidak dapat dihindarkan. Siapapun dapat mengambil perannya, tidak harus seorang komisaris polisi yang terbaring di rumah sakit (Komisaris Gordon), dia bisa polisi biasa namun sarat dengan kemampuan reserse (John Blake), bisa juga seorang pencuri profesional yang turut ingin mengambil peran di sana (Selina Kyle). Ia bisa menjelma menjadi siapapun; ia adalah masyarakat itu sendiri.

TDKR memberikan inspirasi dan harapan di dalamnya, manusia akan senantiasa membutuhkan simbol-simbol untuk menggerakkan. Simbol yang sanggup untuk mempertahankan kesadaran bersama untuk terus bergerak positif dan konstruktif, terus memperbaiki. Simbol tersebut dapat berbentuk apapun atau siapapun.

\section{Simbol Sebagai Harapan di Indonesia}

Lalu bagaimana dengan Indonesia, bangsa yang tengah kelelahan, tersengal-senggal menjalani hidupnya ini tak beda dengan rasa apatis yang menghinggapi masyarakat dalam film TDKR. Sebuah simbol dibutuhkan untuk menjaga harapan dari para komponen bangsa, sebuah simbol yang dapat menjelaskan dengan mudah mengapa kita harus memiliki kesadaran berbangsa yang sama. Kita dapat menyebut bendera merah putih, warna merah putih itu sendiri, dasar negara Pancasila, Lambang Garuda Pancasila, semboyan Bhinneka Tunggal Ika, bentuk kepulauan nusantara, lagu Indonesia Raya, tuturan heroik proklamasi, serta narasi kepahlawanan para patriot bangsa.

Tema fantasi dan bahkan pandangan retorika yang lebih besar, terdiri atas karakter, alur, tempat, dan perantara pendukung (Littlejohn \& Foss, 2009). Sebagai satu contoh simbol, lambang Garuda Pancasila. Karakter burung garuda sedemikian kuatnya sebagai bagian kultur nusantara. Terlebih jika merujuk pada catatan sejarah lahirnya lambang tersebut. Para pendiri bangsa turut ambil bagian secara langsung di dalamnya. Dimulai dengan pembentukan Panitia Indonesia Raya yang diketuai oleh Ki Hajar Dewantara dengan Sekretaris Umum Muhammad Yamin. Panitia ini bertugas menyelidiki arti lambang-lambang peradaban bangsa Indoenesia. Hasilnya berupa kajian data lambang burung Garuda yang terdapat di candi-candi di Pulau Jawa. Sayembara lambang negara sempat diadakan, namun hasilnya tidak memenuhi harapan. Lalu hadir tokoh Sultan Hamid II yang bertugas merancang bentuk lambang negara (saat itu) Republik Indonesia Serikat. Singkat cerita, diperolehlah lambang Garuda Pancasila mendekati bentuk yang saat ini ada. Dengan sekian penyempurnaan, termasuk saran dari presiden Soekarno agar menambahkan jambul pada kepala Garuda serta arah cakar kaki yang mencengkram pita semboyan negara. Maestro Dullah menyempurnakan visual lambang negara tersebut. Pada 17 Oktober 1951 Presiden Soekarno dan Perdana Menteri Sukiman Wirjosandjojo menetapkan PP No. 66 Tahun 1951 tentang Lambang Negara - warna, ukuran, dan bentuk lambang negara. (Kemlu RI, 2012) 
Ketika manusia dapat berbagi tema-tema fantasi, pandangan retorika menyatukan mereka dan memberi pemahaman tentang identifikasi dengan menggunakan sebuah realitas.Kemudian mereka membangun atau mempertahankan kesadaran bersama (shared consciousness) sebuah kelompok atau komunitas (Littlejohn \& Foss, 2009). Ide dari Garuda Pancasila bukan sebagai dokter yang menyembuhkan segala penyakit yang ada. Garuda adalah simbol yang dapat hadir di diri siapapun dalam kelompok atau komunitas, ia memberikan semangat untuk meraih cita-cita yang sama. Ia sanggup menggerakkan tiap elemen masyarakat yang ada untuk bersama memperbaiki lembaga juga struktur yang telah rusak. Ia bisa menjelma menjadi siapapun, mewujud dalam visual, dan ia adalah masyarakat itu sendiri.

\section{Fenomena Jokowi-Ahok}

Ada yang berbeda pada saat pelaksanaan Pemilihan Kepala Daerah (Pilkada) DKI Jakarta. Terdapat sekumpulan masyarakat yang bergerak tanpa komando, bergerak atas inisiatif sendiri memberikan dukungan bagi pasangan Jokowi-Ahok. Lewat berbagai macam bentuk dukungan, dari sekadar kata-kata yang disebar lewat Twitter (Christakis \& Fowler, 2010), membuat film yang diunggah di YouTube, atau sosial media lainnya, hingga dukungan yang sifatnya fisik/tenaga serta materi. Semua bergerak masif membentuk arahnya sendiri dengan satu tujuan yakni dukungan untuk Jokowi-Ahok. Melihat fenomena Jokowi-Ahok di Pilkada DKI Jakarta, penulis yakin fenomena yang terjadi adalah satu bentuk menjaga harapan semisal yang dimiliki oleh Garuda Pancasila. Para pemilih pasangan Jokowi-Ahok telah menjadi pemilih yang tidak gelap mata, yakni pemilih yang tidak sepenuhnya yakin bahwa Jokowi-Ahok adalah obat segala macam penyakit yang ada di ibu kota. Namun yang berjalan adalah mereka (para pemilih) bersama-sama mencoba menjaga harapan, harapan terhadap Jakarta yang lebih baik, serta Indonesia yang lebih baik. Kemudian mereka bersama-sama membangun serta mempertahankan kesadaran bersama untuk mewujudkan kemenangan pasangan pilihannya tersebut. Mereka bergerak bersama demi sebuah harapan yang terjaga.

\section{SIMPULAN}

Lambang Garuda Pancasila, juga pasangan Jokowi-Ahok telah memberikan inspirasi dan harapan di dalamnya. Simbol senantiasa dibutuhkan untuk menggerakkan. Simbol-simbol tersebut diharapkan sanggup untuk mempertahankan kesadaran bersama untuk terus bergerak positif dan konstruktif. Kesadaran untuk terus bergerak dengan tetap terus memperbaiki.

\section{DAFTAR PUSTAKA}

Christakis, N. A. dan Fowler, J. H. (2010). CONNECTED - Dahsyatnya Kekuatan Jejaring Sosial Mengubah Hidup Kita. Jakarta: Gramedia Pustaka Utama.

DC. Comics. (1993). Batman: The Knightfall. USA: DC. Comics.

DC Comics. (1998). Batman: Bane of the Demon 1. USA: DC. Comics.

Kemlu RI. (2012). Timeline Proses Perancangan Lambang Garuda Pancasila.

Littlejohn, S. W. dan Foss, K. A. (2009). Teori Komunikasi. Jakarta: Salemba Humanika.

Nolan, C. (2012) .The Dark Knight Rises. USA: Warner Bross. 


\section{LAMPIRAN}

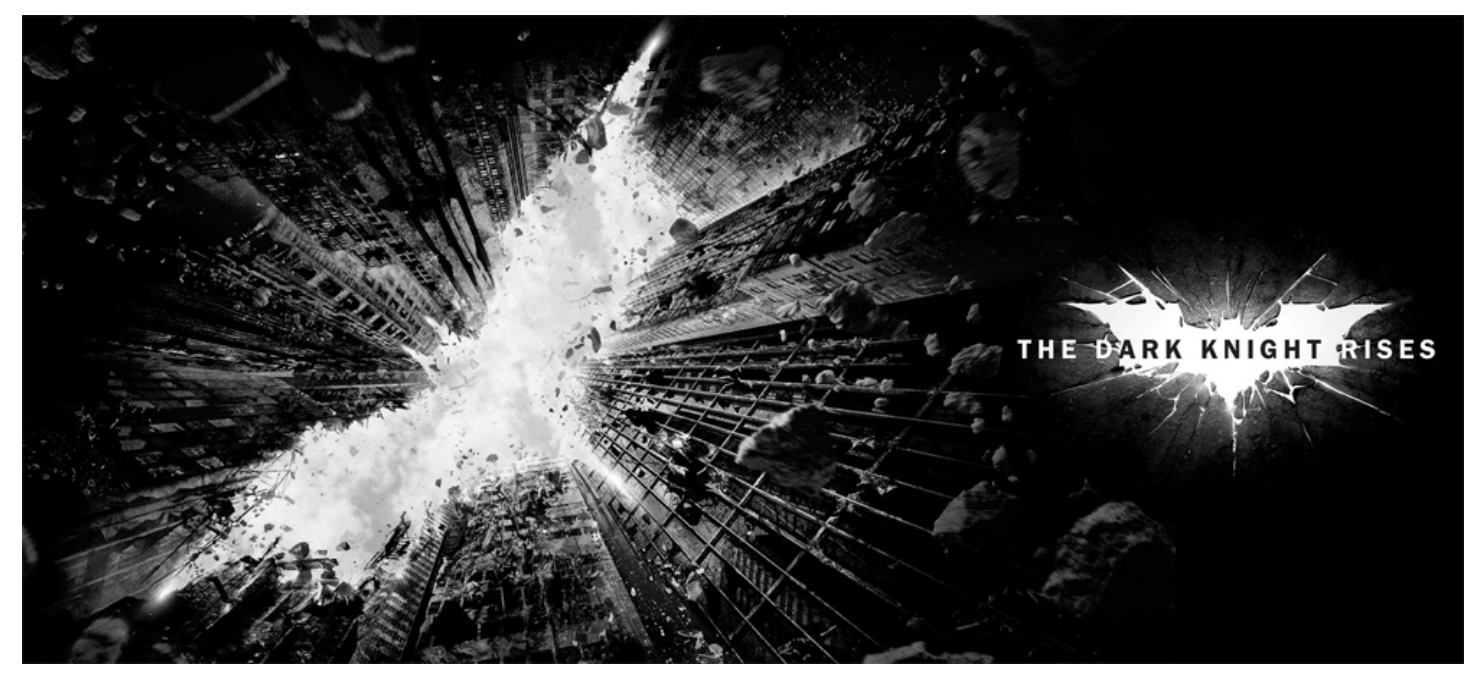

The Dark Knight Rises

Sutradara : Christopher Nolan

Screen Play : Jonathan Nolan \& Christopher Nolan

Penulis Cerita : Christopher Nolan \& David S. Goyer

Studio Produksi : Legendary Pictures, Syncopy Films, DC Comics

Pemeran : Christian Bale, Anne Hathaway, Tom Hardy

Durasi : 165 menit 